\title{
DETERMINAN PERILAKU RUMAH TANGGA DALAM PENGHEMATAN ENERGI LISTRIK DI WILAYAH JAWA BARAT MENGGUNAKAN STRUCTURAL EQUATION MODELING
}

\author{
Siti Sadiah ${ }^{1}$, Fitria Virgantari ${ }^{2}$, Ani Andriyani ${ }^{3}$, Sri Hartini ${ }^{4}$, Dion Ahmad ${ }^{5}$ \\ $1,2,3,4,5$ Universitas Pakuan, Bogor \\ Email: fitriav12@gmail.com
}

\section{KETERANGAN ARTIKEL \\ Riwayat Artikel}

Diterima: 1 November 2019

Direvisi: 10 Desember 2019

Disetujui: 28 Desember 2019

\section{Klasifikasi JEL}

D01

Keywords: electrical energy consumption, theory of planned of behavior, structural equation modelling

Kata kunci: konsumsi energi listrik, theory of planned behaviour, structural equation modelling ABSTRACT
This study aims to analyze the Theory Planned of Behavior model using Structural Equation Modeling and analyze the factors that influence household behavior in electricity consumption in West Java. The data used in this study are secondary data on electricity consumption in lighting equipment obtained from the Renewable Energy and Energy Conservation database in 2016. The results showed that behavioral intention and control had a positive and significant effect on behavior, then behavior control had a positive and significant effect. significant on intention. While subjective attitudes and norms do not significantly influence intention. The indicators that influence a person's behavior factors in saving electrical energy in lighting equipment are individual self-awareness to use household appliances that are labeled energy efficient, lifestyle of individuals who often fill their time for cooking activities at home, gathering with friends and family, visiting market, stamp collection, and individuals who work as volunteers, participate in community activities, and gardening.

\section{ABSTRAK}

Penelitian ini bertujuan untuk menganalisis model Theory Planned of Behaviour menggunakan Structural Equation Modeling dan menganalisis pengaruh faktor-faktor yang mempengaruhi perilaku rumah tangga dalam konsumsi energi listrik di Jawa Barat. Data yang digunakan pada penelitian ini merupakan data sekunder mengenai konsumsi energi lisrik pada peralatan lampu yang diperoleh dari database Energi Baru Terbarukan dan Konservasi Energi tahun 2016. Hasil penelitian menunjukkan bahwa niat dan kontrol perilaku berpengaruh positif dan signifikan terhadap perilaku, kemudian kontrol perilaku berpengaruh positif dan signifikan terhadap niat. Sementara sikap dan norma subjektif tidak secara signifikan mempengaruhi niat. Adapun Indikator-indikator yang mempengaruhi faktor perilaku seseorang dalam melakukan penghematan energi listrik pada peralatan lampu adalah kesadaran diri individu untuk menggunakan peralatan rumah tangga yang berlabel hemat energi, gaya hidup individu yang sering mengisi waktunya untuk kegiatan memasak dirumah, berkumpul dengan teman dan keluarga, mengunjungi pasar, koleksi perangko dan sebagainya, kemudian individu yang bekerja sebagai tenaga sukarela, berpartisipasi pada kegiatan komunitas, dan berkebun. 


\section{PENDAHULUAN}

Energi memiliki peran yang penting bagi kehidupan manusia baik untuk kegiatan industri, kegiatan komersial, rumah tangga maupun pengembangan suatu wilayah atau negara.

Indonesia sebagai negara dengan jumlah penduduk yang besar dapat menyebabkan konsumsi energi yang cenderung meningkat. Menurut Statistik Ketenagalistrikan tahun 2015 konsumsi listrik di Indonesia mengalami pertumbuhan rata-rata $6,8 \%$ per tahun sementara peningkatan pasokan listrik hanya sebesar $4 \%$ per tahun.

Berdasarkan PT. Perusahaan Listrik Negara (PLN) sekitar 74\% daya listrik dikonsumsi di wilayah pulau Jawa-Bali. Jawa Barat merupakan provinsi yang paling besar mengkonsumsi energi listrik di pulau Jawa. Berdasarkan daya tersambung persektor pelanggan di wilayah Jawa Barat, menurut statistik ketenagalistrikan tahun 2015, sektor rumah tangga memiliki daya tersambung paling besar yaitu 8,749.86 Mega Volt Ampere (MVA). Sementara peralatan rumah tangga yang paling banyak digunakan oleh masyarakat adalah lampu, karena lampu merupakan alat rumah tangga paling umum yang dimiliki oleh masyarakat, maka penggunaan lampu dalam sektor rumah tangga memiliki peran yang cukup besar dalam konsumsi energi listrik.

Mengingat pemanfaatan energi listrik yang terus meningkat sedangkan sumber energi ketersediaannya semakin terbatas, maka sumber energi perlu diupayakan pemanfaatannya secara efisien.

Terdapat beberapa studi sebelumnya yang meneliti perilaku masyarakat dan penggunaan energi diantaranya Lynch \& Martin (2013) menggunakan model Theory Planned of Behaviour (TPB), hasil studi menjelaskan bahwa model TPB merupakan model yang valid dalam menjelaskan kekuatan seseorang melakukan perilaku penggunaan energi rumah tangga dan TPB dapat diukur dengan menggunakan metode Structural Equation Modeling (SEM).

Kartika (2018) dan Kartini (2017) melakukan penelitian tentang penggunaan energi dengan analisis deskriptif. Sementara Wijaya dan Tezuka (2013) serta Rusliwando (2016) dalam penelitiannya mengatakan bahwa SEM dapat menjelaskan faktor-faktor yang mempengaruhi perilaku penghuni dalam menggunakan peralatan listrik rumah tangga. Faktor-faktor tersebut yaitu faktor pendapatan, karakteristik rumah tangga, kesadaran diri dan keputusan dalam membeli peralatan listrik dan masih banyak faktor yang belum diteliti lebih dalam.

Berbeda dengan penelitian sebelumnya, penelitian ini bertujuan menganalisis model Theory Planned of Behaviour dengan faktor yang lebih luas.. Selain faktor pendapatan, karakteristik rumah tangga, kesadaran diri dan keputusan dalam membeli peralatan listrik, juga dimasukkan faktor gaya hidup beberapa kelompok responden yang memiliki kebiasaan yang berbeda dalam penggunaan listrik.

\section{KAJIAN LITERATUR DAN PENGEMBANGAN HIPOTESIS}

Teori Perilaku Rencanaan (Theory of Planned Behavior/ TPB)

Theory of Planned Behavior (TPB) yang merupakan pengembangan dari Theory of Reasoned Action (TRA). Jogiyanto (2007) mengembangkan teori ini dengan menambahkan konstruk yang belum ada di TRA. Konstruk ini di sebut dengan kontrol perilaku persepsian (perceived behavioral control). Konstruk ini ditambahkan di TPB untuk mengontrol perilaku individual yang dibatasi oleh kekurangan-kekurangannya dan keterbatasan-keterbatasan dari kekurangan sumber-sumber daya yang digunakan untuk melekukan perilakunya (Hsu and Chiu 2002). Dengan menambahkan sebuah konstruk ini, yaitu kontrol perilaku persepsian, maka bentuk dari model TPB tampak di Gambar 1. 


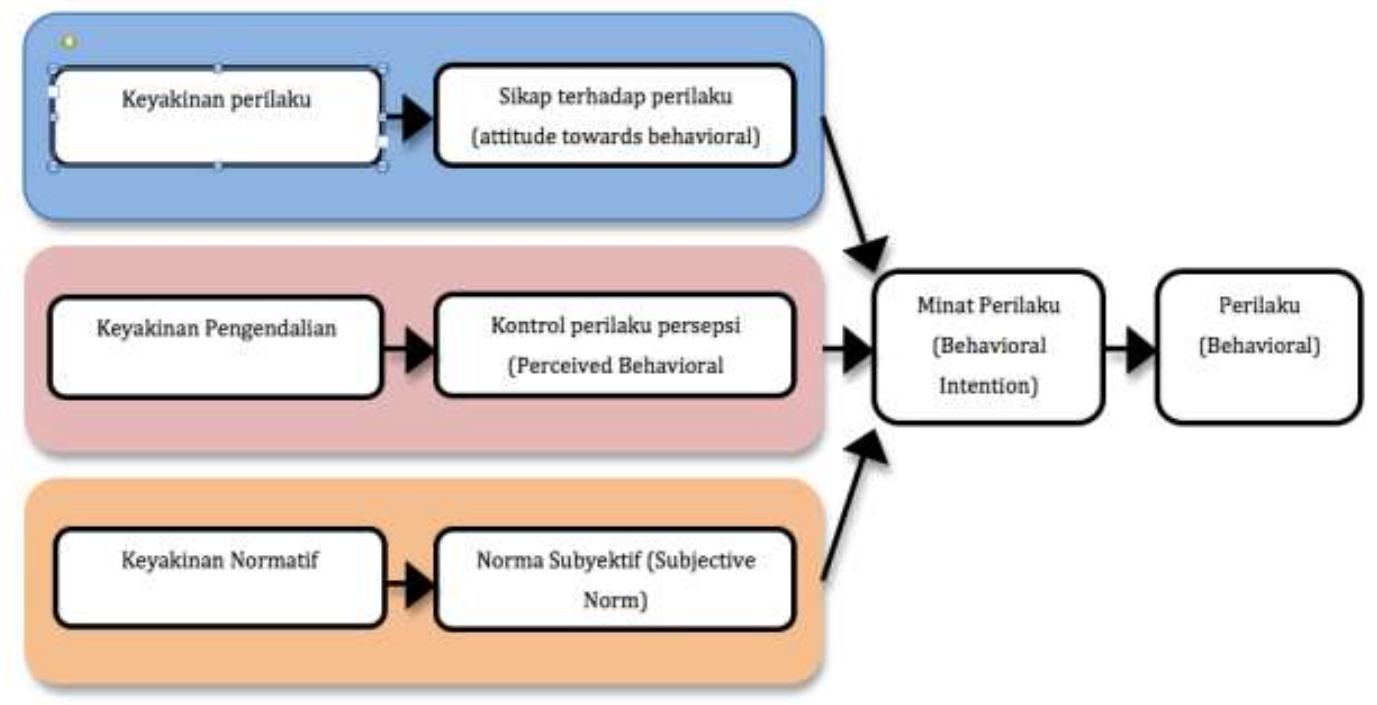

Gambar 1. Teori Perilaku Terencanaan (Theory of Planned Behavioral)

Dari Gambar 1 Theory of Planned Behavior dapat mempunyai dua fitur (Jogiyanto, 2007). Yang pertama, teori ini mengasumsikan bahwa kontrol persepsi perilaku (perceived behavioral control) mempunyai implikasi motivasional terhadap minat. Orang - orang yang percaya bahwa mereka tidak mempunyai sumber-sumber daya yang ada atau tidak mempunyai kesempatan untuk melakukan perilaku tertentu mungkin tidak akan membentuk minat berperilaku yang kuat untuk melakukannya walaupun mereka mempunyai sikap yang positif terhadap perilakunya dan percaya bahwa orang lain akan menyetujui seandainya mereka melakukan perilaku tersebut. Dengan demikian diharapkan terjadi hubungan antara kontrol persepsi perilaku (perceived behavioral control) dengan minat yang tidak dimediasi oleh sikap dan norma subyektif. Di model ini ditunjukkan dengan panah yang mennghubungkan kontrol perilaku persepsian ke minat.

Yang kedua adalah kemungkinan hubungan langsung antara kontrol persepsi perilaku (perceived behavioral control) dengan perilaku. Di banyak contoh, kinerja dari suatu perilaku tergantung tidak hanya pada motivasi untuk melakukannya tetapi juga kontrol yang cukup terhadap perilaku yang dilakukan. Dengan demikian. Kontrol perilaku persepsian (perceived behavioral control) dapat mempengaruhi perilaku secara tidak langsung lewat minat, dan juga dapat memprediksi perilaku secara langsung. Di model hubungan langsung ini ditunjukan dengan panah yang menghubungkan kontrol persepsi perilaku (perceived behavioral control) langsung ke perilaku (behavior).

TPB mengganggap bahwa teori sebelumnya mengenai perilaku yang tidak dapat dikendalikan sebelumnya oleh individu melainkan, juga dipengaruhi oleh faktor mengenai faktor non motivasional yang dianggap sebagai kesempatan atau sumber daya yang dibutuhkan agar perilaku dapat dilakukan. Oleh karena itu menurut TPB, intensi dipengaruhi oleh tiga hal yaitu: sikap, norma subjektif, kontrol perilaku (Ajzen, 2005).

Berbagai studi telah banyak dilakukan mengenai perilaku energi pada rumah tangga yang bertujuan menstimulasi perilaku lebih hemat energi dan mengurangi perilaku konsumsi energi. Abrahamse et al. (2005) menyatakan bahwa konsumsi energi adalah suatu interaksi yang kompleks antara faktor- 
faktor tingkat makro, seperti teknologi, ekonomi, demografis, dan institusional, dan faktor-faktor motivasional, seperti preferensi, sikap, kemampuan, dan peluang. Ajzen (2005) memberikan pemahaman yang lebih luas mengenai perilaku lingkungan, bahwa konsumsi terutama dipengaruhi oleh nilai-nilai sosial dan lingkungan, variabel situasional dan faktor-faktor psikologis.

\section{Structural Equation Modelling (SEM)}

Menurut Mattjik dan Sumertajaya (2011), SEM merupakan salah satu teknik pengolahan data statistik multivariate structural relationship. Menurut Johnson and Wichern (2002) SEM adalah set persamaan linear yang digunakan untuk menentukan fenomena variabel sebab dan akibat.

Terdapat beberapa tujuan SEM, antara lain 1) mendapatkan model struktural yang dapat digunakan untuk keperluan prediksi, dan 2) menguji pengaruh variabel bebas terhadap variabel tidak bebas dan jalur-jalur keterkaitan antar variabel.

Terdapat dua jenis variabel utama dalam SEM yaitu variabel laten dan variabel teramati. Variabel laten merupakan kunci dalam SEM dan dapat diamati melalui pengaruhnya terhadap variabel indikator atau variabel manifes.

Terdapat dua jenis model dalam SEM, yaitu model struktural dan model pengukuran. Model struktural bertujuan untuk memeriksa hubungan yang mendasari atau yang menyusun variabel laten ke dalam model pengukuran dan variabel konstruk lainnya berdasarkan teori. Sedangkan model pengukuran digunakan untuk menduga hubungan antar variabel laten dengan variabelvariabel teramatinya.

Bentuk umum dari model variabel laten adalah:

$$
\begin{aligned}
& \eta_{1}=\gamma_{11} \xi_{1}+\zeta_{1} \\
& \eta_{2}=\beta_{21}+\gamma_{21} \xi_{2}+\zeta_{2}
\end{aligned}
$$

Dalam bentuk matriks persamaan (1) dan (2) dapat dinyatakan sbb:

$$
\eta=\mathrm{B} \eta+\mathrm{T} \xi+\zeta
$$

di mana $\eta$ adalah variabel laten endogen (dependent) berukuran $\mathrm{m} \times 1 ; \quad \xi$ adalah variabel laten eksogen berukuran $\mathrm{n} \times 1$; $\zeta$ adalah galat struktural berukuran $\mathrm{m} \times 1$; $\mathrm{B}$ adalah matriks koefisien untuk variabel laten endogen berukuran $\mathrm{m} \times \mathrm{m}$; dan $\mathrm{T}$ adalah matriks koefisien untuk variabel laten eksogen berukuran $m \times n$ ).

Bentuk umum model pengukuran adalah :

$$
\begin{aligned}
& \mathrm{x}_{1}=\lambda_{1} \xi_{1}+\delta_{1} \\
& \mathrm{x}_{2}=\lambda_{2} \xi_{1}+\delta_{2} \\
& \mathrm{y}_{1}=\lambda_{3} \eta_{1}+\varepsilon_{1} \\
& \mathrm{y}_{2}=\lambda_{3} \eta_{2}+\varepsilon_{2}
\end{aligned}
$$

Dalam bentuk matriks persamaan (4), (5) dan (6), (7) dapat dinyatakan sbb:

$$
\begin{aligned}
& \mathrm{X}=\mathrm{A} \xi+\delta \\
& \mathrm{Y}=\mathrm{A} \eta+\varepsilon
\end{aligned}
$$

di mana

$\boldsymbol{x}$ : indikator variabel laten eksogen dari $\boldsymbol{\xi}$ berukuran $\mathrm{q} \times 1$

$y$ : indikator variabel laten endogen dari $\boldsymbol{\eta}$ berukuran $\mathrm{p} \times 1$

$\delta$ : galat pengukuran dari $\mathrm{x}$ berukuran $\mathrm{q} \times 1$

$\varepsilon$ : galat pengukuran dari y berukuran $\mathrm{q} \times 1$

A: matriks koefisien berkaitan dengan $\mathrm{x}$ dan $\mathrm{y}$ berukuran $\mathrm{q} \times \mathrm{n}$ dan $\mathrm{p} \times \mathrm{m}$

Berdasarkan model persamaan struktural tersebut akan diuji apakah perilaku konsumsi energi rumah tangga di Jawa Barat dipengaruhi oleh intensi sikap, norma subyektif, dan kontrol perlaku berdasarkan variabel-variabel yang telah ditentukan.

\section{METODE PENELITIAN}

Data yang digunakan yaitu data primer dan sekunder yang diperoleh dari database Energi Baru Terbarukan dan Konservasi Energi (EBTKE) mengenai perilaku rumah tangga dalam konservasi energi di wilayah Jawa Barat tahun 2016 dengan 205 responden. Penarikan 
sampel dilakukan secara acak berlapis dan kluster dengan alokasi proporsional.

Variabel yang diamati dalam penelitian ini meliputi faktor perilaku, minat, sikap, norma subyektif dan kontrol perilaku dalam penggunaan lampu sesuai dengan Theory Planned of Behaviour (TPB). Adapun indikator yang digunakan dalam penelitian ini meliputi faktor gaya hidup, demografi dan kesadaran diri. Indikator tersebut disajikan pada Tabel 1.

Tabel 1. Variabel Indikator

\begin{tabular}{|c|c|c|}
\hline \multirow{6}{*}{$\begin{array}{c}\text { Gaya } \\
\text { Hidup } \\
\text { Kelompok } \\
1\left(\mathrm{GH}_{1}\right)\end{array}$} & $\mathrm{X}_{18}$ & $\begin{array}{l}\text { Pergi ke } \\
\text { bioskop/konser/teater }\end{array}$ \\
\hline & $\mathrm{X}_{19}$ & Browsing internet \\
\hline & $\mathrm{X}_{8}$ & Membaca buku \\
\hline & $X_{9}$ & $\begin{array}{l}\text { Bermain game } \\
\text { komputer }\end{array}$ \\
\hline & $\mathrm{X}_{1}$ & Berolahraga \\
\hline & $\mathrm{X}_{2}$ & $\begin{array}{l}\text { Menghabiskan waktu } \\
\text { untuk kegiatan seni } \\
\text { kreatif }\end{array}$ \\
\hline \multirow{4}{*}{$\begin{array}{c}\text { Gaya } \\
\text { Hidup } \\
\text { Kelompok } \\
2\left(\mathrm{GH}_{2}\right)\end{array}$} & $X_{3}$ & $\begin{array}{l}\text { Menghabiskan waktu } \\
\text { untuk kegiatan koleksi }\end{array}$ \\
\hline & $\mathrm{X}_{4}$ & $\begin{array}{l}\text { Bekerja sebagai tenaga } \\
\text { sukarela }\end{array}$ \\
\hline & $x_{5}$ & $\begin{array}{l}\text { Berpartisipasi pada } \\
\text { kegiatan komunitas }\end{array}$ \\
\hline & $\mathrm{X}_{10}$ & Berkebun \\
\hline \multirow{4}{*}{$\begin{array}{c}\text { Gaya } \\
\text { Hidup } \\
\text { Kelompok } \\
\mathbf{3}\left(\mathrm{GH}_{3}\right)\end{array}$} & $\mathrm{X}_{12}$ & Bepergian untuk kuliner \\
\hline & $\mathrm{X}_{13}$ & $\begin{array}{l}\text { Berjalan kaki di kota } \\
\text { atau di taman }\end{array}$ \\
\hline & $\mathrm{X}_{14}$ & $\begin{array}{l}\text { Bersepeda (untuk } \\
\text { berbagai kegiatan) }\end{array}$ \\
\hline & $\mathrm{X}_{16}$ & Mengkonsumsi daging \\
\hline \multirow{2}{*}{$\begin{array}{c}\text { Gaya } \\
\text { Hidup } \\
\text { Kelompok } \\
4\left(\mathrm{GH}_{4}\right)\end{array}$} & $X_{6}$ & $\begin{array}{l}\text { Menghadiri kegiatan } \\
\text { keagamaan }\end{array}$ \\
\hline & $X_{7}$ & Berbelanja \\
\hline \multirow{3}{*}{$\begin{array}{c}\text { Gaya } \\
\text { Hidup } \\
\text { Kelompok } \\
5\left(\mathrm{GH}_{5}\right)\end{array}$} & $\mathrm{X}_{11}$ & Memasak di rumah \\
\hline & $\mathrm{X}_{15}$ & $\begin{array}{l}\text { Berkumpul dengan } \\
\text { teman dan keluarga }\end{array}$ \\
\hline & $\mathrm{X}_{17}$ & Mengunjungi pasar \\
\hline
\end{tabular}

\begin{tabular}{cll}
\hline $\begin{array}{c}\text { Kesadaran } \\
\text { Diri }\end{array}$ & $\mathrm{AW}_{\mathbf{1}}$ & $\begin{array}{l}\text { Pengetahuan mengenai } \\
\text { bagaimana untuk }\end{array}$ \\
\hline
\end{tabular}

\begin{tabular}{|c|c|c|}
\hline & & $\begin{array}{l}\text { menjadi lebih hemat } \\
\text { energi }\end{array}$ \\
\hline & $\mathrm{AW}_{2}$ & $\begin{array}{l}\text { Lebih banyak informasi } \\
\text { terkait dampak } \\
\text { lingkungan dari } \\
\text { pemborosan energi }\end{array}$ \\
\hline & $\mathrm{AW}_{3}$ & $\begin{array}{l}\text { Pendidikan anak } \\
\text { disekolah mengenai } \\
\text { hemat energi }\end{array}$ \\
\hline & $\mathrm{AW}_{4}$ & $\begin{array}{l}\text { Informasi yang lebih } \\
\text { jelas mengenai biaya } \\
\text { operasi saat membeli } \\
\text { peralata rumah tangga }\end{array}$ \\
\hline & $\mathrm{AW}_{5}$ & $\begin{array}{l}\text { Pemberian tanda label } \\
\text { yang lebih baik pada } \\
\text { peralatan rumah tangga }\end{array}$ \\
\hline Demografi & $I_{1}$ & Jenis kelamin \\
\hline & $I_{2}$ & Pendidikan \\
\hline & $I_{3}$ & Pekerjaan \\
\hline & $\mathrm{ID}_{4}$ & Total pendapatan \\
\hline & $\mathrm{ID}_{5}$ & Total pengeluaran listrik \\
\hline & $I_{6}$ & Usia \\
\hline & $\mathrm{ID}_{7}$ & Kapasitas terpasang \\
\hline
\end{tabular}

\section{Tahapan Analisis}

Tahapan Analisis pada penelitian ini sebagai berikut: 
Siti Sadiah: Determinan Perilaku Rumah Tangga ...

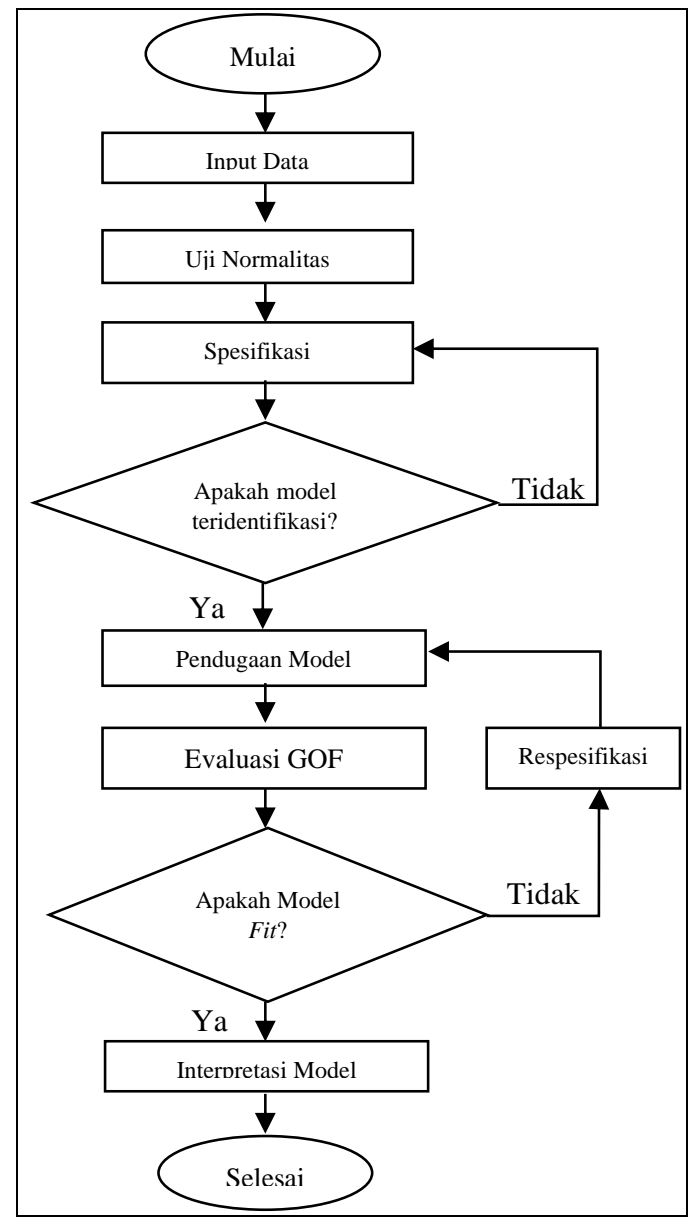

Gambar 1. Diagram Alur Tahapan Analisis.

Pertama, melakukan perhitungan skor bagi faktor sikap, norma subjektif dan kontrol perilaku. Skor sikap dapat dihitung menggunakan rumus sebagai berikut.

$$
A T B=\sum_{i=1}^{n} b_{i} \cdot e_{i}
$$

\section{Keterangan:}

ATB = Sikap konsumen terhadap perilaku tertentu.

$b_{i}=$ Keyakinanan terhadap perilaku

$e_{i}=$ Evaluasi terhadap hasil yang diperoleh dari perilaku.

$n=$ Jumlah keyakinan yang dimiliki seseorang terhadap perilaku tertentu.

Rumus untuk mendapatkan skor dari faktor norma subjektif adalah sebagai berikut.
$S N=\sum_{i=1}^{n} r_{i} \cdot m_{i}$

Keterangan :

$\mathrm{SN}=$ Norma subjektif konsumen .

$r_{i}=$ Keyakinan normatif

$m_{i}=$ Motivasi untuk mematuhi kelompok acuan.

$n=$ Jumlah keyakinan yang dimiliki seseorang terhadap perilaku tertentu.

Rumus untuk mengetahui nilai skor persepsi pengendalian perilaku adalah sebagai berikut.

$$
P B C=\sum_{i=1}^{n} p_{i} \cdot c_{i}
$$

Keterangan:

$\mathrm{PBC}=$ Persepsi pengendalian perilaku.

$p_{i}=$ Keyakinan akan faktor-faktor yang mendorong atau menghalangi suatu perilaku tertentu.

$c_{i}=$ Kekuatan faktor yang mendorong atau menghalangi perilaku.

$n=$ Jumlah keyakinan yang dimiliki seseorang terhadap perilaku tertentu.

Nilai skor dari masing-masing faktor dan data indikator demografi, kesadaran diri serta kelompok gaya hidup yang telah didapatkan, diinputkan kedalam software AMOS 22 untuk dilakukan pendugaan.

Kedua, uji normalitas. Langkah selanjutnya adalah uji normalitas, asumsi normalitas dapat diuji dengan nilai statistik $z$ untuk skewness dan kurtosis. Hasil yang diharapkan adalah $\leq 1.96$ pada taraf $\alpha 5 \%$.

Ketiga, spesifikasi. Model persamaan penelitian ini adalah model TPB, kemudian gambarkan variabel dari model struktural dan model pengukuran kedalam diagram jalur. Selanjutnya gabungkan diagram jalur kedua model tersebut hingga membentuk full model atau hybrid model. Setelah diagram jalur full model terbentuk, lakukan konversi diagram jalur dari setiap pengukuran kedalam persamaan matematika.

Keempat, identifikasi. Identifikasi model adalah proses penentuan agar penduga yang didapatkan adalah tunggal atau unik. Terdapat 3 kemungkinan dalam identifikasi yaitu, just 
identified, over identified dan under-identified. Salah satu metode identifikasi model adalah dengan menggunakan derajat bebas (degree of freedom) atau $d f$. Rumus untuk mendapatkan nilai derajat bebas menurut Wijanto (2008) adalah sebagai berikut.

$$
d f=(p+q)\left(\frac{p+q+1}{2}\right)-t
$$

Keterangan:

$\mathrm{T}=$ Banyak parameter yang diduga.

$P=$ Banyak indikator variabel laten endogen.

$Q=$ Banyak variabel laten eksogen.

Nilai $d f$ yang diharapkan adalah $\geq 0$ atau kemungkinan yang diharapkan adalah just identified atau over identified.

Kelima, pendugaan model. Model penelitian yang telah memenuhi spesifikasi dan identifikasi selanjutnya dilakukan pendugaan model. Jumlah sampel dalam penelitian ini ada sebanyak 205 , sehingga penduga model yang digunakan adalah maximum likelihood. Pendugaan dilakukan dengan menggunakan software AMOS 22.

Keenam, evaluasi Goodness of Fit. Dalam tahap ini, tingkat kecocokan diperiksa antara data dengan model. Model diukur dengan jenis ukuran Absolut Fit Measure dan Incremental Fit Measure. Ukuran GOF yang digunakan adalah GFI, AGFI, NFI dan RMSEA. Jika hasil evaluasi GOF dari masing-masing ukuran memenuhi batas GOF atau menunjukan model yang fit, maka selanjutnya melakukan uji reliabilitas untuk melihat kecocokkan model pengukuran. Rumus untuk menghitung nilai reliabilitas konstruk menurut Haryono \& Wardoyo (2013) adalah sebagai berikut.

$$
\text { reliabilitas }=\frac{\left(\sum \text { std.loading }\right)^{2}}{\left(\sum \text { std.loading }\right)^{2}+\sum e_{j}}
$$

Keterangan:

Standard loading $=$ Nilai standardized loading dari hasil perhitungan AMOS.

$e_{j}=$ Measurement error dari tiap indikator.
Sedangkan kecocokan model struktural, mencakup pemeriksaan terhadap signifikansi koefisien-koefisien yang diduga.

Ketujuh, respesifikasi. Terdapat beberapa cara yang dapat dilakukan dalam memodifikasi model. Modifikasi yang dilakukan dalam tahap ini berdasarkan modification indices yang disarankan oleh program AMOS 22, yaitu: a) menambahkan lintasan baru antar variabel teramati dengan variabel laten dan atau antar variabel laten, dan b) Menambahkan error covariance diantara dua buah error variance.

Kedelapan, interpretasi model. Bila model yang diperoleh telah memenuhi GOF, maka selanjutnya adalah melakukan interpretasi. Interpretasi model struktural yaitu menginterpretasikan faktor-faktor yang dianalisis kemudian interpretasi analisis lintasan yang meliputi kausalitas antar variabel.

\section{HASIL DAN PEMBAHASAN}

\section{Deskripsi Responden}

Deskripsi responden dari penelitian ini menggunakan bantuan program SPSS adalah sebagai berikut.

Tabel 2. Jenis Kelamin Responden

\begin{tabular}{l|c|c}
\hline Jenis Kelamin & Frekuensi & Persentase \\
\hline Laki-laki & 68 & 33,2 \\
\hline Perempuan & 137 & 66,8 \\
\hline Total & 205 & 100 \\
\hline
\end{tabular}

Berdasarkan Tabel 2, jumlah reponden dalam penelitian didominasi dengan jenis kelamin perempuan berjumlah 137 orang dan responden dengan jenis kelamin laki-laki ada sebanyak 68 orang.

Tabel 3. Pendidikan Responden 
Siti Sadiah: Determinan Perilaku Rumah Tangga ...

\begin{tabular}{l|c|c}
\hline \multicolumn{1}{c|}{ Pendidikan } & Frekuensi & Persentase \\
\hline $\begin{array}{l}\text { Tidak menjalani } \\
\text { pendidikan formal }\end{array}$ & 2 & 1,0 \\
\hline $\begin{array}{l}\text { Tidak menyelasaikan } \\
\text { SD }\end{array}$ & 9 & 4,4 \\
\hline Tamat SD & 36 & 17,6 \\
\hline Tamat SMP & 36 & 17,6 \\
\hline Tamat SMA & 83 & 40,5 \\
\hline Diploma & 7 & 3,4 \\
\hline S1 atau D4 & 26 & 12,7 \\
\hline Master/Doktor & 6 & 2,9 \\
\hline Total & 205 & 100 \\
\hline
\end{tabular}

\begin{tabular}{l|c|c}
\hline Variabel & Skewness & Kurtosis \\
\hline $\begin{array}{l}\text { Kontrol } \\
\text { perilaku }\end{array}$ & -0.017 & -1.306 \\
\hline $\begin{array}{l}\text { Norma } \\
\text { subjektif }\end{array}$ & 0.338 & -0.605 \\
\hline Sikap & 0.618 & -0.133 \\
\hline Niat & 1.276 & 0.116 \\
\hline Perilaku & 0.486 & -0.153 \\
\hline Multivariat & & 1.729 \\
\hline
\end{tabular}

Hasil pengujian menunjukkan bahwa, nilai $Z_{\text {kurtosis }}$ dan $Z_{\text {skewness }}$ pada setiap

Tabel 3 menunjukkan bahwa responden terbanyak memiliki tingkat pendidikan tamat SMA, sebanyak 83 orang. Sementara tingkat pendidikan paling sedikit ada pada responden yang tidak menjalani pendidikan formal, sebanyak 2 orang.

\section{Uji Normalitas}

Apabila nilai $Z_{\text {kurtosis }}$ dan atau $Z_{\text {skewness }}$ tidak signifikan $(\leq 1.96)$ pada tingkat $5 \%$, dapat dikatakan bahwa data distribusi normal. Hasil uji normalitas yang diperoleh menggunakan software AMOS, disajikan pada Tabel 4 berikut.

Tabel 4. Hasil Uji Normalitas

\begin{tabular}{l|c|c}
\hline Variabel & Skewness & Kurtosis \\
\hline $\mathrm{GH}_{5}$ & -0.481 & -0.244 \\
\hline $\mathrm{GH}_{4}$ & -0.418 & -0.517 \\
\hline $\mathrm{GH}_{3}$ & 0.571 & -0.207 \\
\hline $\mathrm{GH}_{2}$ & 0.856 & 1.002 \\
\hline $\mathrm{GH}_{1}$ & 1.174 & 0.869 \\
\hline $\mathrm{AW}_{5}$ & 0.069 & -0.429 \\
\hline $\mathrm{AW}_{4}$ & 0.023 & 1.891 \\
\hline $\mathrm{AW}_{3}$ & -0.293 & 0.049 \\
\hline $\mathrm{AW}_{2}$ & -0.101 & 0.589 \\
\hline $\mathrm{AW}_{1}$ & 0.139 & 1.618 \\
\hline $\mathrm{ID}_{7}$ & 0.098 & -1.557 \\
\hline $\mathrm{ID}_{6}$ & 0.406 & -0.338 \\
\hline $\mathrm{ID}_{5}$ & 0.942 & 0.530 \\
\hline $\mathrm{ID}_{4}$ & 0.467 & 0.132 \\
\hline $\mathrm{ID}_{3}$ & 0.467 & -1.516 \\
\hline $\mathrm{ID}_{2}$ & 0.154 & -0.166 \\
\hline $\mathrm{ID}_{1}$ & -0.797 & -1.365 \\
\hline & &
\end{tabular}
indikator $\mathrm{GH}_{1}, \mathrm{GH}_{2}, \mathrm{GH}_{3}, \mathrm{GH}_{4}, \mathrm{GH}_{5}, \mathrm{AW}_{1}, \mathrm{AW}_{2}$ $A W_{3}, A W_{4}, A W_{5}, I D_{1}, I D_{2}, I D_{3}, I D_{4}, I D_{5}, I D_{6}, I D_{7}$ dan variabel sikap, kontrol perilaku, norma subjektif, niat dan perilaku memiliki nilai $\leq 1.96$. sehingga dapat diartikan bahwa data dalam penelitian ini berdistribusi normal.

\section{Spesifikasi}

Model yang digunakan dalam penelitian ini adalah model TPB, model terdiri dari model struktural dan model pengukuran. Berdasarkan teori perilaku perencanaan tersebut, selanjutnya kedua model tersebut dibuat diagram jalur hubungan kausalitas antar faktor. Input grafik yang dibuat dengan program AMOS disajikan pada Gambar 2.

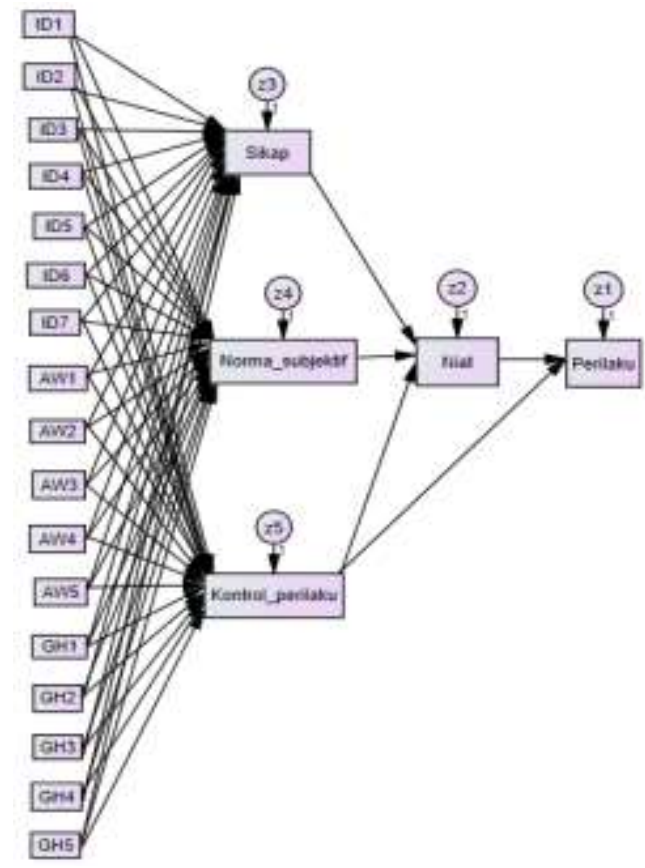

Gambar 2. Diagram Jalur Hybird Model 
Gambar 2 merupakan model hybird atau penggabungan model struktural dengan model pengukuran menjadi model simultan.

\section{Konversi Diagram Jalur ke dalam Persamaan Struktural dan Model Pengukuran}

Persamaan model struktural dapat dituliskan sebagai berikut.

Perilaku $=\beta_{21}$ Niat $+\gamma_{31}$ Kontrol Perilaku Niat $=\gamma_{12}$ Sikap $+\gamma_{22}$ Norma Subjektif

$+\gamma_{32}$ Kontrol Perilaku

Persamaan model pengukuran

$$
\begin{gathered}
\text { Sikap }=\lambda_{11} I D_{1}+\lambda_{21} I D_{2}+\lambda_{31} I D_{3}+\cdots \\
+\lambda_{171} G H_{5} \\
\text { Norma Subjektif }=\lambda_{12} I D_{1}+\lambda_{22} I D_{2}+ \\
\lambda_{32} I D_{3}+\cdots+\lambda_{172} G H_{5} \\
\text { Kontrol Perilaku }=\lambda_{13} I D_{1}+\lambda_{23} I D_{2}+ \\
\lambda_{33} I D_{3}+\cdots+\lambda_{173} G H_{5}
\end{gathered}
$$

\section{Identifikasi Model}

Identifikasi dapat dihitung dengan melihat nilai derajat bebas, jumlah variabel yang digunakan ada sebanyak 22 dan jumlah parameter yang akan diduga ada sebanyak 78 , sehingga nilai derajat bebas yang diperoleh (22 $x(22+1) / 2)-78=175$. Karena nilai derajat bebas $>0$, maka dapat disimpulkan bawa model teridentifikasi atau over indentified.

\section{Pendugaan Model}

Pendugaan model dilakukan untuk memperoleh nilai dari parameter-parameter yang ada di dalam model. Berdasarkan output Regression Weight pada software AMOS, indikator $I D_{1}, I D_{2}, I D_{3}, I D_{4}, I D_{5}, I D_{6}, I D_{7}, A W_{1}, A W_{2}$, $\mathrm{AW}_{3}, \mathrm{GH}_{2}, \mathrm{GH}_{3}$ dan $\mathrm{GH}_{5}$ pada konstruk sikap tidak signifikan karena nilai $P>0.05$.

Selanjutnya indikator $I D_{1}, I D_{3}, I D_{4}, I D_{5}, I D_{6}$, $\mathrm{ID}_{7}, \mathrm{AW}_{1}, \mathrm{AW}_{2}, \mathrm{AW}_{3}$ dan $\mathrm{GH}_{1}$ pada konstruk norma subjektif juga tidak signifikan karena nilai $P>0.05$ dan indikator $I D_{1}, I D_{2}, I D_{3}, I D_{4}, I D_{5}$, $I D_{6}, I_{7}, A W_{1}, A_{2}, A W_{3}, A_{4}, G_{1}$ dan $\mathrm{GH}_{4}$ pada konstruk kontrol perilaku tidak signifikan. Sehingga indikator tersebut harus dikeluarkan dari pengujian dan dilakukan pengujian ulang. Model baru yang terbentuk, disajikan pada Gambar 3.

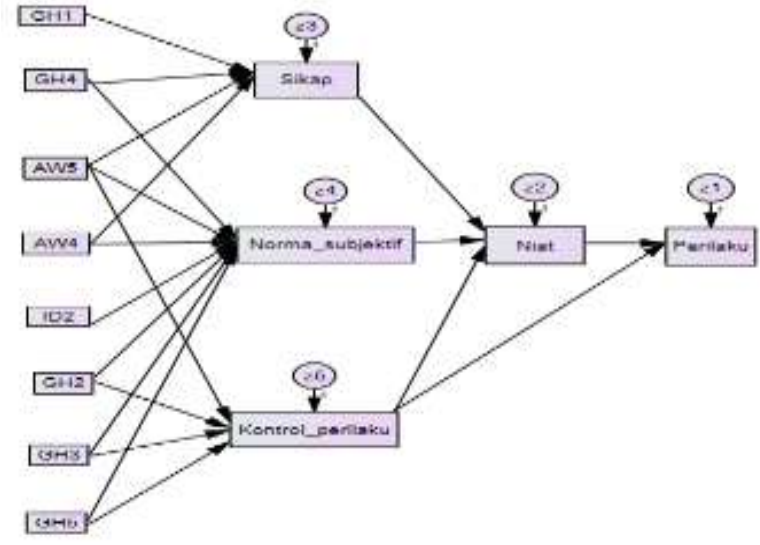

Gambar 3. Diagram Jalur Modifikasi Model

Berdasarkan Gambar 3, variabel indikator yang masuk dalam pendugaan yaitu $I_{2}, \mathrm{AW}_{4}, \mathrm{AW}_{5}, \mathrm{GH}_{1}, \mathrm{GH}_{2}, \mathrm{GH}_{3}, \mathrm{GH}_{4}$ dan $\mathrm{GH}_{5}$. Adapun koefisien parameter dari model struktural dan pengukuran yang diperoleh adalah sebagai berikut.

Persamaan model struktural:

$$
\text { Perilaku }=0.41 \mathrm{~N}+0.35 \mathrm{KP}
$$

Niat $=-0.19 S+0.08 N S-0.91 K P$

Keterangan:

$\mathrm{N}=$ Niat

$\mathrm{KP}=$ Kontrol Perilaku

NS $=$ Norma Subjektif

$S=$ Sikap

$\mathrm{KP}=$ Kontrol Perilaku

Persamaan model pengukuran:

Sikap $=0.03 \mathrm{GH}_{1}-0.03 \mathrm{GH}_{4}+0.10 \mathrm{AW}$ $+0.08 \mathrm{AW}_{4}$

Norma Subjektif $=0.05 \mathrm{GH}_{4}+0.08 \mathrm{AW}_{5}$ $+0.07 \mathrm{AW}_{4}+0.01 \mathrm{ID}_{2}-0.04 \mathrm{GH}_{2}$ $-0.04 \mathrm{GH}_{3}-0.04 \mathrm{GH}_{5}$

Kontrol Perilaku $=0.08 \mathrm{AW}_{5}-0.02 \mathrm{GH}_{2}$ $-0.02 \mathrm{GH}_{2}+0.02 \mathrm{GH}_{5}$

\section{Evaluasi Goodness of Fit}

Kriteria yang menjadi acuan dalam penelitian ini adalah AGFI, GFI, RMSEA, dan NFI. Hasil analisis ukuran-ukuran GOF disajikan pada Tabel 5. 
Siti Sadiah: Determinan Perilaku Rumah Tangga ...

Tabel 5. Hasil Evaluasi GOF

\begin{tabular}{|c|c|c|c|}
\hline Ukuran & Kriteria GOF & $\begin{array}{c}\text { Hasil } \\
\text { Pendugaan }\end{array}$ & $\begin{array}{c}\text { Tingkat } \\
\text { Kecocokan }\end{array}$ \\
\hline $\mathrm{NFI}$ & $\begin{array}{l}\text { NFI } \geq 0.90 \\
\text { good fit, } \\
0.80 \leq \\
N F I< \\
0.90 \text { margin } \\
\text { al fit. }\end{array}$ & 0.607 & $\begin{array}{c}\text { Kurang } \\
\text { baik }\end{array}$ \\
\hline AGFI & $\begin{array}{l}\text { AGFI } \geq 0.90 \\
\text { good fit, } \\
0.80 \leq \\
A G F I< \\
0.90 \text { margin } \\
\text { al fit. }\end{array}$ & 0.715 & $\begin{array}{c}\text { Kurang } \\
\text { baik }\end{array}$ \\
\hline GFI & $\begin{array}{l}\text { GFI } \geq 0.90 \\
\text { good fit, } \\
0.80 \leq \\
G F I< \\
0.90 \text { margin } \\
\text { al fit. }\end{array}$ & 0.818 & Marjinal \\
\hline RMSEA & $\begin{array}{l}\text { RMSEA } \leq \\
0.80 \text { good fit }\end{array}$ & 0.150 & $\begin{array}{c}\text { Kurang } \\
\text { baik }\end{array}$ \\
\hline
\end{tabular}

Tabel 5 menunjukkan bahwa nilai GFI dikatakan marjinal, karena berada pada selang 0.8 hingga 0.9. Sementara nilai NFI, AGFI dan RMSEA kurang baik, karena nilai dari tiap pengukuran masih dibawah kriteria GOF. Sehingga perlu dilakukan respesifikasi atau modifikasi model.

\section{Respesifikasi}

Modifikasi yang dilakukan berdasarkan Modification Indice (MI) yang disarankan oleh software AMOS. Output MI disajikan pada Tabel 6 berikut.

Tabel 6. Modification Indice Modification Indice

\begin{tabular}{|c|c|}
\hline GH1 $\longleftrightarrow-->$ ID2 & 22.969 \\
\hline GH2 & 5.310 \\
\hline AW5 <--> GH1 & 7.920 \\
\hline AW5 $<-->$ AW4 & 72.677 \\
\hline AW5 <--> GH3 & 5.087 \\
\hline AW5 <--> GH2 & 7.742 \\
\hline$z 3<-->z 5$ & 33.888 \\
\hline$z 1<-->z 4$ & 5.224 \\
\hline Z1 <--> Z3 & 5.820 \\
\hline
\end{tabular}

Berdasarkan Tabel 6, maka modifikasi model yang disarankan oleh software AMOS adalah dengan menghubungkan indikator $\mathrm{GH}_{1}$ dengan $\mathrm{ID}_{2}$, indikator $\mathrm{GH}_{2}$ dengan $\mathrm{AW}_{4}$, kemudian menghubungkan indikator $\mathrm{AW}_{5}$ dengan $\mathrm{GH}_{1}, \mathrm{AW}_{4}, \mathrm{GH}_{3}$ dan $\mathrm{GH}_{2}$, selanjutnya menghubungkan error z3 dengan z5 serta menghubungkan error $\mathrm{z} 1$ dengan error $\mathrm{z} 3$ dan z4. Setelah dilakukan modifikasi, duga kembali model dan evaluasi kembali GOFnya.

Hasil pendugaan akhir yang diperoleh, menunjukkan indikator $\mathrm{AW}_{5}, \mathrm{GH}_{2}$ dan $\mathrm{GH}_{5}$ pada konstruk kontrol perilaku. Indikator $\mathrm{GH}_{4}, \mathrm{AW}_{5}$, dan $\mathrm{GH}_{1}$ pada konstruk sikap dan indikator $\mathrm{GH}_{4}$, $\mathrm{ID}_{2}, \mathrm{AW}_{4}, \mathrm{AW}_{5}, \mathrm{GH}_{5}, \mathrm{GH}_{2}$ dan $\mathrm{GH}_{3}$ pada kontruk norma subjektif, seluruhnya telah signifikan karena memiliki nilai $P>0.05$, sehingga model sudah dapat digunakan. Diagram jalur dari fit model dapat dilihat pada Gambar 4. 


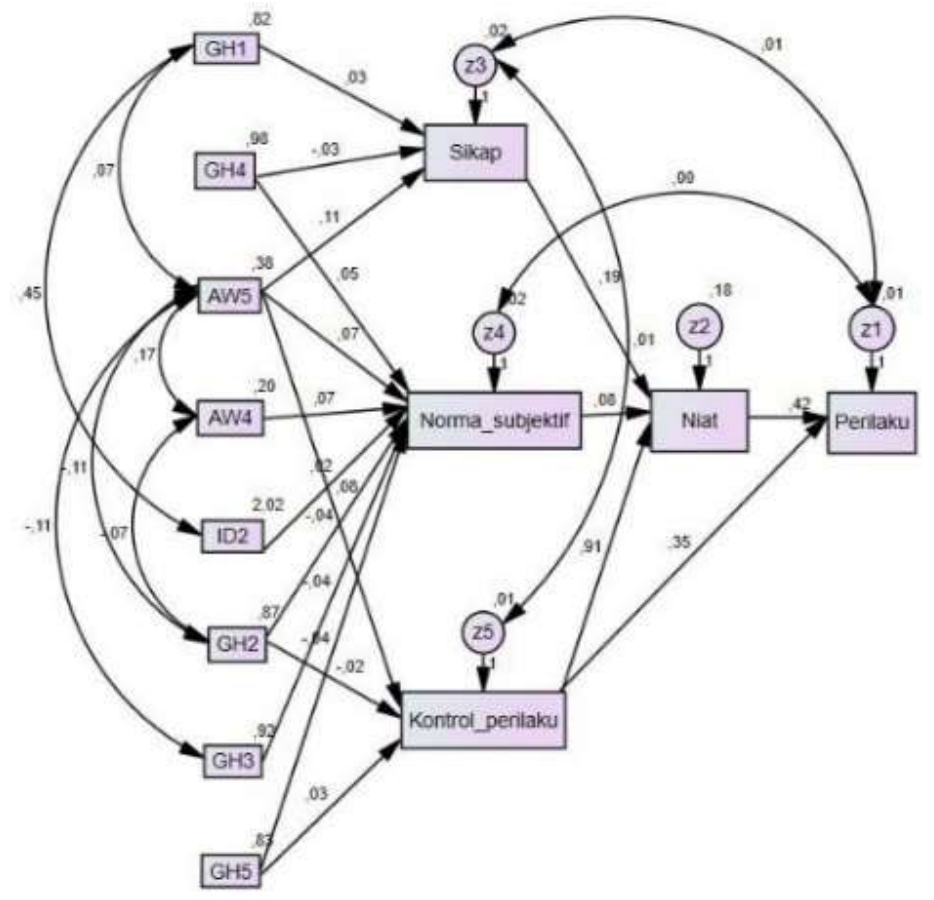

Gambar 4. Diagram Jalur Fit Model

Gambar 4 merupakan diagram jalur dari fit model yang digunakan. Adapun persamaan model struktural yang diperoleh yaitu:

Persamaan model struktural:

Perilaku $=0.42 \mathrm{~N}+0.35 \mathrm{KP}$

Niat $=-0.19 S+0.08 N S-0.91 K P$

Keterangan:

$\mathrm{N}=$ Niat

$\mathrm{KP}=$ Kontrol Perilaku

NS $=$ Norma Subjektif

$S=$ Sikap

$\mathrm{KP}=$ Kontrol Perilaku

Persamaan model pengukuran

Sikap $=0.03 G_{1}-0.03 G H_{4}+0.11 A W_{5}$

Norma Subjektif $=0.05 \mathrm{GH}_{4}+0.07 \mathrm{AW}_{5}$

$+0.07 \mathrm{AW}_{4}+0.02 \mathrm{ID}_{2}-0.04 \mathrm{GH}_{2}$

$-0.04 \mathrm{GH}_{3}-0.04 \mathrm{GH}_{5}$

Kontrol Perilaku $=0.08 \mathrm{AW}_{5}-0.02 \mathrm{GH}_{2}$ $-0.02 \mathrm{GH}_{2}+0.03 \mathrm{GH}_{5}$

Setelah model terbentuk, maka lakukan evaluasi GOF untuk melihat apakah model yang dihipotesiskan cocok dengan data yang diobservasi atau tidak Nilai dari ukuran GOF disajikan pada Tabel 7 berikut.

Tabel 7. Hasil Evaluasi GOF Fit Model

\begin{tabular}{|c|c|c|c|}
\hline Ukuran & Kriteria GOF & $\begin{array}{l}\text { Hasil } \\
\text { Pendugaan }\end{array}$ & $\begin{array}{l}\text { Tingkat } \\
\text { Kecocokan }\end{array}$ \\
\hline NFI & $\begin{array}{l}\mathrm{NFI} \geq 0.90 \\
\text { good fit, } \\
0.80 \leq N F I< \\
0.90 \text { marginal } \\
\text { fit. }\end{array}$ & 0.872 & Marjinal \\
\hline AGFI & $\begin{array}{l}\text { AGFI } \geq 0.90 \\
\text { good fit, } \\
0.80 \leq \\
\text { AGFI }< \\
0.90 \text { marginal } \\
\text { fit. }\end{array}$ & 0.872 & Marjinal \\
\hline GFI & $\begin{array}{l}\mathrm{GFI} \geq 0.90 \\
\text { good fit, } \\
0.80 \leq G F I< \\
0.90 \text { marginal } \\
\text { fit. }\end{array}$ & 0.928 & Baik \\
\hline RMSEA & $\begin{array}{l}\text { RMSEA } \leq \\
0.80 \text { good fit }\end{array}$ & 0.069 & Baik \\
\hline
\end{tabular}


Tabel 7 menunjukkan bahwa hasil evaluasi GOF pada ukuran GFI memiliki tingkat kecocokan yang baik karena nilai GFI yang diperoleh sebesar $0.928 \geq 0.928$, ukuran RMSEA dapat dikatakan baik karena memiliki nilai sebesar $0.069 \leq 0.08$. Sementara untuk ukuran NFI dan AGFI dapat dikatakan marjinal, karena memiliki nilai yang berada pada selang 0.80 sampai 0.90 , maka dapat disimpulkan bahwa model yang dihasilkan baik.

\section{Interpretasi Model}

Berdasarkan fit model yang diperoleh pada tahap sebelumnya, maka persamaan model struktural yang didapatkan sebagai berikut.

Perilaku $=0.42 N+0.35 K P$

Niat $=-0.19 S+0.08 N S-0.91 K P$

Keterangan:

$\mathrm{N}=$ Niat

$\mathrm{KP}=$ Kontrol Perilaku

NS $=$ Norma Subjektif

$S=$ Sikap

$\mathrm{KP}=$ Kontrol Perilaku

Berdasarkan persamaan model struktural disimpulkan bahwa niat dan kontrol perilaku berpengaruh positif dan signifikan terhadap perilaku. Hal ini berarti semakin tinggi niat untuk melakukan penghematan energi listrik dan semakin tinggi persepsi individu terhadap kemampuannya dalam melakukan penghematan energi listrik, maka akan semakin tinggi perilaku individu dalam melakukan penghematan energi listrik pada lampu.

Sikap dan norma subjektif berpengaruh positif tetapi tidak signifikan terhadap niat, sementara kontrol perilaku berpengaruh positif dan signifikan. Hal ini berarti semakin tinggi persepsi individu terhadap kemampuannya dalam melakukan penghematan energi listrik, maka semakin tinggi niat individu untuk melakukan penghematan energi listrik pada peralatan lampu.

Adapun koefisien determinasi dari setiap model dan koefisien model simultan yang diperoleh disajikan pada Tabel 8.

Tabel 8. Koefisien Determinasi $\left(\mathbf{R}^{2}\right)$

\begin{tabular}{ll}
\hline Model & $\mathbf{R}^{\mathbf{2}}$ \\
\hline Niat & 0.617 \\
\hline Perilaku & 0.795 \\
\hline Model & 0.700 \\
simultan & \\
\hline
\end{tabular}

Berdasarkan nilai koefisien determinasi $\left(R^{2}\right)$ pada Tabel 8, model struktural perilaku memiliki nilai $R^{2}$ sebesar 0.79 . Hal ini berarti faktor niat dan kontrol perilaku memberikan pengaruh terhadap perilaku sebesar $79.5 \%$. Model struktural niat memiliki nilai $\mathrm{R}^{2}$ sebesar 0.617, hal ini berarti faktor sikap, kontrol perilaku dan norma subjektif memberikan pengaruh terhadap niat sebesar $61.7 \%$.

Nilai $R^{2}$ model simultan adalah sebesar 70\%. Hal ini berarti faktor sikap, norma subjektif, kontrol perilaku dan niat mempengaruhi perilaku hemat energi listrik pada peralatan lampu sebesar $70 \%$, sisanya sebesar $30 \%$ dipengaruhi oleh faktor lain.

\section{PENUTUP}

Berdasarkan model Theory Planned of Behaviour yang dianalisis menggunakan Structural Equation Modeling dapat disimpulkan bahwa niat dan kontrol perilaku berpengaruh positif dan signifikan terhadap perilaku. Hal ini berarti semakin tinggi niat untuk menghemat energi listrik dan semakin tinggi persepsi seseorang terhadap kemampuannya untuk melakukan penghematan energi maka akan semakin tinggi perilaku seseorang dalam melakukan penghematan energi listrik pada peralatan lampu. Faktor sikap dan norma subjektif tidak secara signifikan mempengaruhi niat, sementara kontrol perilaku berpengaruh signifikan terhadap niat. Hal ini berarti semakin tinggi persepsi seseorang terhadap 
kemampuannya untuk melakukan penghematan energi maka semakin tinggi niat untuk melakukan penghematan energi listrik pada peralatan lampu.

Indikator-indikator yang mempengaruhi faktor perilaku dan niat seseorang dalam melakukan penghematan energi listrik pada peralatan lampu adalah kesadaran diri individu untuk menggunakan peralatan rumah tangga yang berlabel hemat energi, gaya hidup individu yang sering mengisi waktunya untuk kegiatan memasak dirumah, berkumpul dengan teman dan keluarga, mengunjungi pasar, koleksi koin dan sebagainya. Kemudian individu yang bekerja sebagai tenaga sukarela, berpartisipasi pada kegiatan komunitas dan berkebun.

Saran dalam penelitian ini adalah pada penelitian selanjutnya, dapat ditambahkan variabel indikator misalnya faktor regulasi/kebijakan, ketersediaan teknologi, tarif, lingkungan, serta faktor sosial budaya; sehingga model yang dihasilkan dapat lebih menggambarkan karakteristik responden di wilayah Jawa Barat dalam berperilaku hemat energi.

Salah satu cara meningkatkan perilaku konservasi energi listrik, pemerintah Jawa Barat perlu meningkatkan sosialisasi program konservasi energi dan dampak lingkungan terkait pemborosan energi, agar masyarakat dapat mengatur gaya hidupnya dan memiliki kesadaran diri untuk menggunakan peralatan rumah tangga yang berlabel hemat energi.

\section{REFERENSI}

Abrahamse, W and Steg, L. (2011). Factors Related to Household Energy Use anda Intention to Reduce It: The Role of Psychological and Socio-Demographic Variables. Human Ecology Review. Vol 18 No. 1. Pp 30-40.

Ajzen, I. (2005). Attitude, Personality, and Behavior. 2nd Edition. Berkshire. UK: Open University Press-McGraw Hill Education.
Dewan Energi Nasional Republik Indonesia. (2014). Ketahanan Enrgi Indonesia. Jakarta

Haryono, S. dan P. Wardoyo. (2013). Structural Equation Modeling untuk Penelitian Manajemen Menggunakan AMOS 18.00. Bekasi: Intermedia Personalia Utama.

Hsu, M. H. and Chiu, C. M. (2002). "Predicting Electronic Service Continuance with a Decomposed Theory of Planned Behavior, "Behavior \& Information Technology.

Jogiyanto. (2007). Teori Portofolio dan Analisis Investasi, Edisi 2007, Cetakan Pertama. Yogyakarta: BPFE Yogyakarta.

Johnson and Wichern. (2002). Multivariate Analysis. New York: McGraw-Hill.

Kartika, S. (2018). Analisis Konsumsi Energi dan Program Konservasi Energi: Studi Kasus Gedung Perkantoran dan Kompleks Perumahan. Jurnal Sebatik Vol 22 (2), pp. 41-50.

Kartini, P. (2017). Analisis Statistik Konsumsi Energi Listrik pada Bangunan Gedung Yayasan Widya Dharma Pontianank. Jurnal Elkha. Vol 9 (2) pp 45-52.

Lynch, D. and P. Martin. (2013). How Energy Efficiency Programs Influence Energy Use: An Application of The Theory Of Planned Behaviour. ECEE Summer Study Proceedings. 2037-2048.

Mattjik, A.A. dan I.M. Sumertajaya. (2011). Sidik Peubah Ganda. Institut Pertanian Bogor.

Rusliwando, F. S. (2016). Analisis Faktor-Faktor yang Mempengaruhi Perilaku Konsumsi Energi Listrik Menggunakan Partial Least Square Structural Equation Modeling. Fakultas Teknik, Universitas Widyatama Bandung.

Wijanto, S. H. (2008). Structural Equation Modeling dengan LISREL 8.80: Konsep dan Tutorial. Yogyakarta: Graha IImu.

Wijaya, E. dan Tezuka. (2013). Policy Making for Household Appliances-Related Electricity Consumption in Indonesia- A 
Multicultural Country. Open Journal of Energy Efficiency pp 53-64. 